\title{
Between Monsoon Wedding and Behind Enemy Lines
}

\author{
By Rod Stoneman
}

Fall 2002 Issue of KINEMA

\section{ALL GENERALISATIONS ARE FALSE: BETWEEN MONSOON WEDDING AND BE- HIND ENEMY LINES}

To start at the end of Monsoon Wedding: hidden amongst the end credits, as a roller caption goes by, cutting to fast flashbacks of shots from the exhilarating musical finale, there is concealed amongst the lists of production personnel a three line note:

"We are like that.

40 locations 30 days.

exactly and approximately."

There are always the perverse pleasures of discovering a hidden code -- there at the edge of the text. (I remember the most radical aspect of Pier Paolo Pasolini's Salo, aside from the explicit sexual cruelty, was the bibliography he supplied in the end credits: Barthes, De Sade, Sollers).

It is only cinephiles who stay in the emptying cinema for the credits and then amongst them only a tiny minority who would understand an obscure reference to the shoot schedule.

"We are like that" -- a necessarily defiant assertion of cultural specificity in relation to the pervasive centripetal pull of Western Culture. The film was entirely shot in Delhi and, for anyone familiar with the modalities of film production, the implications of "40 locations in 30 days" is an indication of a six week schedule (or five weeks if you film for an exhausting six days a week). Suffice it to say this was a very intense production process, achieving an average of over three minutes of final material on each day of filming. It also constitutes an extremely fast turn around between locations, even if they are all in the same city. The "exactly and approximately" is a marvellous oxymoronic quotation from P.K. Dube, a Mr Fix-it character who opens the film and also provides one of the narrative denouements.

There have also been word of mouth rumours of a significant insurance claim, when one reel was apparently wiped out by an airport x-ray. There is always the specificity of the adventure of every film's shoot with its group dynamics, its authentic anxieties and excitements, in its decisive encounter with the contingent.

Monsoon Wedding is a musical, light and colourful film, with its five intersecting stories it also has a meaningful social engagement with issues of class, caste in relation to gender political questions -- abuse, sister hood, arranged marriage. Perhaps it is too bald to list these topics in this way as though the film is just a vessel containing this 'content' (to use the mercantile term of the digital era); it is a cinematic experience and not some sort of sociological agenda. If Monsoon Wedding is a powerful film it is the way that these progressive 'engagements' are integrated into its form. Indeed it would also be facile to approach a film like Behind Enemy Lines purely in terms of a simple critique of its reactionary 'content'. Both films are their modes of production and the way their cultural and political perspectives are inscribed in and through their texts.

Mira Nair's film moves in and out of different languages: Hindi, English and Punjabi, sometimes within single sentences -- the actual weaving of diverse tongues in post-colonial India. The paradox of English language production is that whilst it gives greater access to the world market it also leads to greater penetration of American movies with the home audience. Whether French, Mexican or Icelandic, national cinemas that speak a language other than English have a degree of local protection.

The historical imposition of English constitutes something of an ambiguous advantage, as ex-Minister of Culture Michael D. Higgins put it "the Irish people thank the British for the unsolicited gift of the English Language." Hollywood's rare moments of subtitling, such as The Longest Day and Dances with Wolves, are tolerated but subtitling is generally an inhibition for the wider multiplex-going audience, they are used to films, which speak the imperial tongue. In many cases this may lead to culturally clumsy transpositions; Capt Corelli's Mandolin and Chocolat being recent pusillanimous examples. In Eloge d'Amour, Jean Luc 
Godard, with characteristic dark irony, has two children in Breton national dress knock at the front door of the house with a petition to have The Matrix dubbed into the Breton language...

Listening to the texture of tongues in Monsoon Wedding I was aware that the presence of this mostly subtitled Indian film in the Galway Omniplex was already notable, exceptional, poignant. The statistics behind the subjective impression of the strangeness of its presence are stark enough: $94 \%$ of the films shown in Ireland are American product.

Other aspects of the international exchange rate are also not good:

Europe in US $4 \%$ of market share

US in Europe $71 \%$ of market share

Europe in Europe 22.5\% market share

In Ireland Monsoon Wedding had a modest publicity and advertising ( $\mathrm{P} \& \mathrm{~A}$ ) budget of $€ 20,000$, it was launched with four prints and by the end of its run it had earned €180,000 at the box office here. For a 'small' film this is a good return.

Later that Saturday afternoon in January at the Galway Omniplex I also saw Behind Enemy Lines with Adam, my 13 year old son; clearly a very different kind of film but cinematic pleasure can be found in diverse genres and types of cinema. Its scale and FX make it instantly clear we are watching a studio financed action film. The film begins and ends on an American aircraft carrier somewhere in the Adriatic. US troops have been pulled into a frustratingly constrained peacekeeping role by the UN. A navy pilot is shot down over Serbian held territory and is ruthlessly pursued by enemy troops, the Americans finally send a rescue mission.

Many sequences display fast, adept editing, articulating a mobility of memory through cross references and flashbacks. As Darren Aronofsky's Requiem for a Dream also indicates, electronic non-linear editing with Avid and Lightworks have replaced the physical, linear Steenbeck and Moviola editing and this technology has had its effect on style and form. The Irish director John Moore had worked in advertising for some years and had apparently been spotted by producer Jerry Bruckhiemer as a result of a Sega commercial. In 1994 Bord Scannán na hÉireann helped complete the stylish short he made He Shoots He Scores.

Incidentally both these features were shot by Irish cinematographers: Declan Quinn and Brendan Galvin. It is an adjacent index for the growth of the indigenous Irish industry over the last decade, whilst it is not a skills base for export intended to service others, but it is an indication of the accumulation of a critical mass of talent in a national context, that can be deployed into the hybridity of the international.

Not too many minutes into Behind Enemy Lines my son, who has precociously picked up some film-making grammar, mutters "plant and pay off" as a journalist talking of the crucial role of news coverage in the Balkan conflict is set up in the early stages. Then, when he throws his clearly readable Sky TV News business card on the Captain's desk Adam is leaning across to alert me to "product placement" in loud tones. We had recently witnessed the pervasive role of Federal Express in the Tom Hanks' film Castaway, but I was curious this time -- why not use CNN, a bigger global network? But then it dawned on me: what connects $20^{\text {th }}$ Century Fox that made this film and Sky Television? Of course it is Rupert Murdoch that owns both!

Like much of contemporary Hollywood this film conforms to Christopher Vogler's version of intrinsic narrative structure outlined in The Writer's Journey an underlying template arguably found extensively in storytelling and explicitly utilised in the economy of American cinematic narrative. Its dramatic structure is also underpinned by the character of the pilot, Burnett, played by Owen Wilson working through traditional Oedipal structures with Gene Hackman's Captain; a degree of this male psychology also plays into his buddy relationship with Gabriel Macht, the other pilot.

Leaving aside a sequence where Burnett plays hopscotch in a minefield triggered by wires, one problem I had in relation to this otherwise effective and pleasurable spectacle of an action movie was the totally unfeasible moment at the end where Burnett jumps off a cliff face and hangs on by one hand as he is rescued from certain death by a US helicopter. "Plausibility is always sacrificed for video game spectacle" as one critic put it. 
These momentary disconcertions notwithstanding, when talking of the racy pleasures of this film, one is immediately clear that a central reason for the dominance of American cinema is the way in which its finely tuned industrial machinery makes powerful and effective films -- to deliver such exhilaration, involvement and pleasure.

But the ideological work of this film is not too far below the surface. The confusion of America's identity and position in the world is displaced onto a European field of conflict. American heroism emerges from a terrain of dark chaos. The motivation to self-sacrifice in "some corner of a foreign field" is imperialism hiding behind nationalism, the same as the earlier British equivalent - the empire that was in Rupert Brooke's mind when he wrote The Soldier in 1915. In fact Admiral Reigart's return of his letter of resignation to Burnett recalls an exactly equivalent moment used by Rudyard Kipling in Gunga Din in 1939.

And it is the bureaucratic timidity of the smooth talking, politically minded French commander that thwarts the rescue to begin with. As it happens, this is a contrast to the brave and proactive French UN commander in another Balkan film - Danis Tanovic's No Man's Land. Two different and interesting perceptions and positionings of the meaning of French roles and identities are at play.

I remember, after seeing Neil Jordan's Michael Collins, Frank Price (who ran Columbia Studios both before and after David Puttnam's unsuccessful time there in Eighties) shared some LA folk wisdom with me in an aside "I'll never greenlight a film about a civil war - the audience can't tell the good guys from the bad guys..." The problems involved in these Manichean moral distinctions and positionings comes to mind when Burnett hitches a lift in the back of a pick up truck with armed Bosnians. How can we tell good Bosnians from bad Bosnians? But Behind Enemy Lines immediately indicates we are amongst the good guys because the pick up truck is blasting Céline Dion, one of the unshaven youths in the back is wearing an Ice Cube t-shirt, and, for the avoidance of doubt, they offer Burnett a swig from their bottle of Coke. In short foreigners can only be related to in so far as they are americanised.

Talking of advertising, one does not have to look much further than the Sky News and Coca Cola for significant product placement. The whole film was made in co-operation with US Defence Department; if you get to use US aircraft carrier you can be sure that the relevant personnel in the military industrial complex have taken a detailed view of the script and its political meaning. It is not to adopt a paranoidconspiratorial worldview to expect Power to defend its own interests.

It's difficult not to interpret the aircraft carrier crew's extensive jubilant applause for Burnett's safe return to his ship gaining impetus from the post 9/11 mental shifts taking place in America as it seeks to renegotiate its role in the world. As the LA Times put it recently, the country needs to understand that "The first reason why they hate us is because we don't know why they hate us." Of course the film's uninhibited exposition of exhilaration and relief is mixed with more dubious meanings for the rest of the world - the hegemony of American confidence. It only underlines the degree to which America remains staunchly ignorant and dismissive of the ninety percent of the planet that is not the United States.

Writing in Sight and Sound, John Wrathall criticises the propagandistic dimension and adds "It comes as a surprise that this jingoistic claptrap was directed by an Irishman, not an American..." -- a breathtaking display of naivety and an ignorance of politics in post-colonial Ireland.

In comparing studio financed films about recent wars a more interesting example would be David O. Russell's Three Kings; which also deploys something of the same free visual style with memory shots and hypothetical images playing into the same action genre. However what distinguishes this film is an entirely more interesting ideological negotiation. Real complexity and contradiction is evident when the three US soldiers enter a bunker where Iraqi soldiers have hidden shelves of television, video players and computers. We enter the Aladdin's cave with a black soldier (played by Ice Cube, the same rap artist who appears on the Bosnian T-shirt in Behind Enemy Lines). As he glances at the images playing on one monitor we see the notorious video footage of Rodney King being beaten senseless by the Los Angeles Police Department.

Later Troy (Mark Wahlberg) refuses to kill his Iraqi torturer because he has been afforded some understanding of the motive behind the man's commitment - the death of his innocent family as a result of a previous American bombing. In contrast to the articulation of such unresolved complexities and contradictions Behind 
Enemy Lines merely works through righteous indignation at images of Balkan genocide to reiterate that American global power is neutral and not self-interested.

Behind Enemy Lines was released by $20^{\text {th }}$ Century Fox with a P \& A budget of $€ 200,000$ and 56 prints in Ireland. The Irish Box office return was €827,000. Behind Enemy Lines has almost exactly ten times the P \& A spend and fourteen times as many prints as Monsoon Wedding, but at €180,000 Mira Nair's film managed to take almost a quarter as much of the income of the American film on a much smaller print run and a tiny publicity budget. Interestingly the average take for each print of Monsoon Wedding was €45,000 in comparison to $€ 15,000$ for each print of Behind Enemy Lines.

Although John Moore has clearly made a much bigger film, seen by many more people than Monsoon Wedding, both in Ireland and world wide, the return per print (a crucial calculation in distribution and exhibition), of the smaller film is significantly better. Indeed the 'gearing' (the ratio of production cost to box office return) of the Indian film can be argued, in relative terms, to constitute a certain financial advantage.

What the general imbalance shows us is the scale of the cultural assault -- US studio films pushed into the market as part of a self-fulfilling prophecy. It is difficult to underestimate the seriousness of the situation we face; "It's like standing in a burning library" as Alpha Oumar Konare, the President of Mali, put it. However the contrast of these two films in the specific territory of Ireland may lead one to think that it is a situation in which strong and independent films may make successful interventions.

(This article is based on a presentation at 'Keeping it Real' a conference held at University College Dublin on 20 April 2002.)

\section{Author Information}

Rod STONEMAN is Director to Huston School of Film and Digital Media, National University of Ireland in Galway. He previously served as Chief Executive of the Irish Film Board and a deputy commissioning editor of independent film and video at Channel Four. He has made several independent programmes for television (including "Between Object and Image," "Ireland: The Silent Voices," and "Italy: The Image Business"), written for Screen, Sight and Sound, Framework, and Afterimage. 